\title{
Author Correction: Constitutive alterations in vesicular trafficking increase the sensitivity of cells from celiac disease patients to gliadin
}

Giuliana Lania, Merlin Nanayakkara, Mariantonia Maglio, Renata Auricchio, Monia Porpora, Mariangela Conte, Maria Antonietta De Matteis, Riccardo Rizzo, Alberto Luini, Valentina Discepolo, Riccardo Troncone, Salvatore Auricchio \& Maria Vittoria Barone

Correction to: Communications Biology https://doi.org/10.1038/s42003-019-0443-1, published online 20 May 2019.

In the original published version of this article the grant number attributed to the Italian Society for Celiac Disease (Associazione Italiana Celiachia; AIC) was incorrectly given as Project No.053_FC_2013. The correct grant number is Grant 005_FC_2016, awarded to Monia Porpora. The error has been corrected in the HTML and PDF versions of the article.

Published online: 02 April 2020

\footnotetext{
(c) (i) Open Access This article is licensed under a Creative Commons Attribution 4.0 International License, which permits use, sharing, adaptation, distribution and reproduction in any medium or format, as long as you give appropriate credit to the original author(s) and the source, provide a link to the Creative Commons license, and indicate if changes were made. The images or other third party material in this article are included in the article's Creative Commons license, unless indicated otherwise in a credit line to the material. If material is not included in the article's Creative Commons license and your intended use is not permitted by statutory regulation or exceeds the permitted use, you will need to obtain permission directly from the copyright holder. To view a copy of this license, visit http://creativecommons.org/licenses/by/4.0/.
}

(c) The Author(s) 2020 